\title{
Orchidaceae Juss. in Flora of Chechnya and Their Protection
}

\author{
E L Tasueva1, R S Magomadova1, A S Abdurzakova1, A M Umaeva², Z I \\ Shakhgirieva², Kh R Khanaeva1, B A Khasueva1, and E R Baibatyrova1 \\ ${ }^{1}$ Faculty of Natural Sciences, Chechen State Pedagogical University, Grozny, Russia \\ ${ }^{2}$ Faculty of Biology, Chechen State University, Grozny, Russia
}

\section{Abstract}

For the first time, perennial materials on the Orchidacaeae Juss. family of Chechnya are summarized 6 consisting of 15 families and 29 species. The largest genus in the family -- Orchis $L$. is represented by 8 species. The article presents information that all members of the family are protected plants listed in the Red Book of Chechnya, Ingushetia, Dagestan and the Stavropol Territory. Some species are not included in the list of plants to be protected, including those species that have underground tuberoids and can serve as a source of salep (for instance, Platanthera bifolia, P. chlorantha, Herminium monorchis, Traunsteinera sphaerica, Dactylorhisa incarnata, D. salina,

Corresponding Author:

E L Tasueva

elizatasu@mail.ru

Received: 25 October 2019 Accepted: 15 November 2019 Published: 25 November 2019

Publishing services provided by Knowledge E

(c) E L Tasueva et al. This article is distributed under the terms of the Creative Commons

Attribution License, which permits unrestricted use and redistribution provided that the original author and source are credited.

Selection and Peer-review under the responsibility of the AgroSMART 2019 Conference Committee.

\section{G OPEN ACCESS}

D. urvilleana). In this connection, data on the resources of family members and the potential possibilities of their use as a medicinal raw material are of interest. We have carried out resource studies of the most common species of Orchis tridentata Scop, within the North Caucasus. The obtained data allow us to expand our understanding of the species role of Orchidaceae Juss family. Полученные данные позВоляют расширить предстаВление о роли ВидоВ семейстВа Orchidaceae Juss. of the North Caucasus flora in the composition of vegetation cover.

Keywords: species, flora, Orchidacae family, resources, Chechnya.

\section{Introduction}

Family Orchidaceae Juss. is the largest family of angiosperms, numbering, according to different authors, from 20,000 to 35,000 species being common cosmopolitan, but mainly in tropical areas, especially in Southeast Asia and tropical America. The temperate latitudes of the northern hemisphere account for about $4.5 \%$ of the species of this family (approximately 900 species); there are 120 species of orchid in the whole Europe [1]. 59 species grow in the Caucasus [2, 3], 41 species grow in the North Caucasus [4]. Flora of the Pre-Caucasus includes 35 species of this family (Ivanov, 1998), 31 species of which are found in the Stavropol Territory [5]. There are 29 species on the territory of Chechnya [6]. 
One of the current trends in the study of vegetation cover is the research and conservation of biodiversity, the part of which are representatives of Orchidaceae Juss. family. This problem is considered among the priority areas of basic research. There are a lot of literature data on the study of this family in various areas with a temperate climate [7--13] and etc.

Representatives of Orchidaceae Juss. family are one of the most vulnerable components of phytocenoses due to the characteristics of biology. All members of the family deserve to be included in the regional Red Books and lists of protected plants. A careful study of geographic distribution, ecology and taxonomy is the first step towards the organization of their protection. It is particularly important to identify relict habitats of individual species, the distribution of rare and subendemic species, as well as species that are on the verge of extinction.

The need to revise the species composition of the orchid family for the flora of the North Caucasus is also due to the fact that first volume of the same name edition, A.I. Galushko [4] did not include the territory of the Black Sea coast, which is orographically related to North-West Transcaucasia (the southern macroslope of the Main Caucasus Range from the vicinity of Novorossiysk to Adler). This territory is also not included in the "Flora of Georgia". In addition, part of the territory of the North-Western Pre-Caucasus, namely the territory of Rostov region, which is located south of the Kumo-Manych cavity and the mouth of the Don, entered territorially into the "Flora of the Lower Don" [14] and was also not counted in the "Flora of the North Caucasus".

The representatives of the family (Orchidaceae) of Chechnya are in various ecological and coenotic conditions due to the border position in the range of their coenopopulation. This explains the relatively small number of species in the local flora and the small number of local populations. Due to the high ornamental nature of the family members and the general popularity of orchids among the population and collectors, as well as the high biological and ecological specialization of species, it is necessary to develop measures for their protection in natural conditions. In this regard, it seems relevant to identify representatives of the genus in regional flora, to study the characteristics of their distribution, abundance, ecological coenotic affinity, as well as expert assessment of the state of their natural populations.

To date, the genus has not been audited within Chechnya. Although information about the family representatives of the republic is contained in large floristic reports, such as "Flora of the USSR", "Flora of the North Caucasus", "Determinant of plants of haymaking and pastures of the North Caucasus", etc. 
In the regional literature there are also quite a few sources that make it possible to fully reveal the species composition of orchid in Chechnya. First of all, these are the classic works of A.A. Galushko, M.U. Umarov, M.A. Taysumov and others.

\section{Methods and Materials}

The object for floristic studies is species of the Orchidaceae Juss family. in the flora of Chechnya. The work was carried out at the Faculty of Natural Sciences of Chechen State Pedagogical University (ChSPU). Research was conducted in the period of 2017--2018 in the republic. A total of 50 herbarium leaves of plants were collected, determined and mounted. In addition, herbarium specimens from CI RAS and ChGPU funds, collected in the study area in different years, were processed.

Taxonomic identification of the collected plants was carried out according to the 3 volumes of "Flora of the North Caucasus" by A.I. Galushko and "Determinant of Caucasian plants" by A.A. Grossgeim. The definition correctness was checked by comparison with morphological description of "Flora of the USSR" and "Flora of the Caucasus" by A.A. Grossgeim, and for species not included in these reports --according to the diagnoses in the original sources. In addition to these publications, a summary of S.K. Cherepanov was used to clarify the types.

\section{Results}

Almost all members of the family found in Chechnya are listed in the regional Red Book, and 17 species of (Cephalanthera damasonium (Mill.) Druce C. longifolia (L.) Fritsch., C. rubra (L.) Rich, Cypripedium calceolus L., Dactylorhiza triphylla (C. Koch) Czer., Limodorum abortivum (L.) Sw., Orchis militaris L., O. picta Loisel., O. purpurea Huds., O. simia Lam., O. tridentata Scop., O. ustulata L., Traunsteinera sphaerica (Bieb.) Schlecht., Cephalanthera rubra, Cypripedium calceolus, Orchis militaris, O. ustulata) -- in the Red Book of Russia. An analysis of this group distribution of rarities by administrative feature of the North Caucasus, in comparison with Chechnya, showed their weak geographical differentiation. Almost all the Orchid Data of the Red Books of Russia are registered in various administrative regions and republics of the North Caucasus. This indicates a wide range of representatives of this taxon.

We have obtained the first results of retrospective floristic monitoring, indicating the depletion of the species composition of orchid in Chechnya as a result of the specific habitats destruction. Thus, as a result of military operations and the creation of various 
industrial facilities in the late 20th century and at the beginning of the 21st century, huge areas of growing orchid species were destroyed on the territory of Chechnya.

Genetic fund of any regional flora is formed in the course of a long evolution and now provides the possibility of the existence of species populations in modern physiographic environment.

However, this environment significantly changes under the influence of man, which leads to the extinction of not only local populations, but also whole species.

The preservation of the genetic fund of flora, especially regional, is of utmost importance not only for practical purposes, but also for theoretical constructions related to the history of the flora formation of a given territory.

The process of species extinction is natural (including plant species). Each species lives for a certain period of time and eventually disappears. There are no such species among the members of the Orchidaceae Juss family in the flora of the North Caucasus; their ranges are sufficiently large to maintain the vitality of the species at a sufficient level. As for the local populations of individual species, the picture is different. In many cases, they reduce their numbers, and some of them completely disappear.

The extinction process of local orchid populations is greatly accelerated by man. Mass preparation of medical raw materials, cattle grazing, picking up bouquets of certain species are the main factors leading to a strong reduction in the ranges of many members of this family.

The basis for the protection of the genetic fund is based on the fact that the entire flora must be preserved for scientific and practical purposes [15].

The flora protection is an indispensable condition for the rational use of plant resources and the reconstruction of vegetation cover [16].

The Orchidacea Juss. family in this respect is in a special position due to the peculiarities of biology and ecology, namely, the reduced degree of seed renewal associated with special conditions of seed germination and its structure.

For the first time, the issue of orchid conservation was raised in Europe at the end of the $19^{\text {th }}$ century, namely in Switzerland, where it was decided to protect Cypripedium calceolus, which became the first protected species. In the $20^{\text {th }}$ century, this problem was repeatedly discussed, including the $7^{\text {th }}$ World Botanical Congress, held in 1975 in Leningrad [13].

All Orchidaceae Juss family representatives of the flora of the North Caucasus are included in the list of the Convention on International Trade of Endangered Species of wild fauna and flora (CITES), signed on March 3, 1973 in Washington, where contracting 
states admitted that wild fauna and flora are indispensable part of the natural systems of the Earth, which must be preserved for present and future generations; and international protection is necessary to protect certain species of wild fauna and flora from overexploitation in international trade. The Convention entered into force in 1975.

On the whole, rather extensive literature is devoted to the protection of orchids of temperate latitudes, including Chechnya. Many species are listed in regional Red Books.

The beginning of work on the study of flora protection in modern period should be considered the decision of taking into account plant species of the USSR flora needed for protection, which was adopted in 1972 by the All-Union Botanical Society, Scientific Council of the USSR Academy of Sciences on the problem "Biological bases of rational use, transformation and protection of flora" and the Plant Life Protection Section of the Organizational Committee of the $12^{\text {th }}$ International Botanical Congress, initiated by academicians E.M. Lavrenko and A.L. Takhtadzhian.

As a result, a list of rare and endangered plants of the USSR flora was compiled, numbering about 4,000 species. Among them, representatives of the Orchidaceae Juss. family consisted of 25 species, only 18 were recorded in the North Caucasus.

Many researchers of the North Caucasus flora who published lists of plants to be protected in the regions worked on the problem of protecting rare plant species, including orchids.

Particular publications were published on plant conservation in many regions of the North Caucasus.

It should be noted that the only regional edition, which includes all Orchidaceae Juss. family representatives, growing within the administrative boundaries, is the Red Book of the Stavropol Territory [17].

Selection criteria determined by the regional strategy of environmental management are used to compile a list of botanical objects for protection. The list of criteria by which the selection of species for the compilation of the All-Union and All-Russian lists is carried out $[15,18,19]$. The category of protection means the importance degree of preserving the genetic fund of a given species. By this criterion, the regional species to be protected are divided into five categories.

Category I. Regional endemics, the distribution of which is often limited to local areas or they are known from several places.

Species of this category should be subject to primary protection regardless of the state of populations or the clarity of systematic isolation as carriers of the rarest and most unique genetic pool. There are no such species among the orchids of Chechnya. 
Category II. Subendemics whose ranges extend beyond the region to adjacent territories - Caucasian, Caucasian-Lazistan and Caucasian-Iranian endemics (4 species): Traunsteinera sphaerica, Dactylorhiza urvilleana, D. euxina, D. salina.

Category III. Relict species having isolated local areas of ranges in the region: glacial relics of boreal, European and Caucasian origin. We have only one type: Cypripedium calceolus.

Category IV. Glacial relics with more extensive ranges both in the republic and beyond; species in the country on the border of the range; heavily exploited medical plants; bouquets of decorative types. This includes Dactylorhiza urvilleana (Steudel) Baumann et Kunkele (D. triphylla (C.Koch)Czer.) all other species of the family.

Category V. Species not included in the first four categories, rare for natural reasons. This category includes 9 species of Cephalanthera damasonium (Mill.) Druce, Cephalanthera longifolia(L.)Fritsch, Cephalanthera rubra (L.) Rich., Orchis coriophora L., Orchis militaris L., Orchis purpurea Huds., Orchis tridentata Scop., Orchis ustulata L., Traunsteinera sphaerica (Bieb.) Schlechter.

The species status describes the state of populations in nature and corresponds to the designations adopted in the Red Book of the International Union for Nature Conservation (IUNC) (IUCN Plant Red Data Book), in the list of rare, threatened and endemic plants in Europe (List of rare, threatened and endemic plants in Europe), in the Red Book of the USSR, in the Red Book of RSFSR.

0 -- species that have presumably disappeared, whose presence in the region has not been confirmed over the past few decades. These are the species whose location is indicated in the literature or there are charges in a single copy. There are 3 species with this status: Cypripedium calceolus.

1 -- species occurring in single specimens, known from one to two or several places, under immediate threat of extinction -- endangered species. These include one kind: Orchis simia.

2 -- species, the number of individuals whose populations are reduced for natural reasons or under the influence of changes (destruction) of the habitat and other anthropogenic factors that are vulnerable. These species are not subject to direct threat of extinction, but are found either in a small amount or in limited territories and in specific ecological niches. There is 1 species with this status: Platanthera bifolia.

3 -- species whose distribution is limited to small areas or distractedly distributed in large areas, which are not currently threatened with extinction, but nevertheless 
their numbers are reducing -- diminishing species. These species include all other representatives of the family ( 31 species).

4 -- the species on the populations status of which there is currently no information, having any of the statuses already listed -- indeterminate species. There are no such species among orchid in Chechnya.

Thus, all members of the Orchidaceae Juss. family of the North Caucasus and NorthWest Transcaucasia are subject to protection and must be included in the Red Book of the Southern Federal District being prepared for publication, the idea of which has been repeatedly discussed by the scientific community.

The main limiting factor for orchids is anthropogenic. Human activities, namely the preparation of medical raw materials (in addition to direct disturbance of habitats), leads to a significant reduction in the number of species or the complete disappearance of local populations.

Representatives of the Orchidaceae Juss. family, which have underground tuberoids, are a source of herbal medicinal raw materials - salep.

Salep mucus is used in medical practice as an excellent enveloping agent for phlogistic diseases of the gastrointestinal tract (catarrh, gastritis, colitis, peptic ulcer), as well as catarrh of the upper respiratory tract, poisoning with various toxic substances $[20,21]$ and etc.). The most commonly used species are Orchis genuses (round salep), and Dactylorhiza, Platanthera, Gymnadenia (palmate salep).

Representatives of the Orchidaceae Juss. family are often mentioned in the literature containing information about medical plants [22--25] and etc.). These and many other sources are designed for the general population who carry out uncontrolled preparation of medical raw materials for self-treatment and for sale, including the underground organs of orchids.

On the other hand, quite a lot of literary sources, including foreign ones, devoted to medicinal plants and oriented to the general population, do not contain information about medical raw materials based on species of the family [26--31] and etc.). Apparently, in this case, publishers and authors adhere to the rules of non-dissemination of information on protected species that may be sources of medical raw materials.

Official procurement of medical raw materials is regulated [32, 33], which, according to the order of the Ministry of Healthcare, is considered the State Pharmacopoeia of the Russian Federation. There are no representatives of the orchid family in the list of harvested species, since all of them are protected plants. 
However, according to the latest information, the State Register of Medicinal Products approved for use in medical practice and for industrial production has been significantly replenished and all species of the genus have been included in it, such as Orchis, Dactylorhiza и Platanthera, and Anacamptis piramidalis, Gymnadenia conopsea, living in the North Caucasus, noted in the publication of the Areas of medicinal and related plants [22].

By international agreement, all orchidaceous are subject to protection as rare plants and their use is possible only when they are introduced into the crop. There is no experience of cultivating orchids on an industrial scale as a source of medical raw materials; therefore, the above-mentioned document assumes its preparation in nature, which will contribute to the extinction of many rare species. In this regard, the preparation can be carried out in limited quantities by trained assemblers who have the appropriate license approved by environmental authorities. According to our data, only one of the most widespread species, Orchis tridentata, can be subject to such preparation in limited quantities.

\section{Conclusion}

Almost all species of the Orchidaceae Juss. family of the Republican flora are protected on the territory of Chechnya. In the studied territory, 14 species are subject to protection and must be included in the Red Book of the Southern Federal District being prepared for publication.

Orchids on the territory of the Chechen Republic, as well as the flora in general, are under study. Especially it concerns hard-to-reach high-mountainous and arid territories -- the Alpine belt, rocks, slope detritus, arid basins. There is no doubt that their detailed research will be added to our list, as well as significantly expand our understanding of relics, endemism, scientific and practical importance of the representatives of this family.

\section{References}

[1] Gladkova, V.N. (1982). Orchid family (Orchidaceae Juss.). I Plant Life, vol. 6, pp. 248-275 .

[2] Grossheim, A.A. (1940). Flora of the Caucasus, 2rd. ed. Baku: AzFAN Publishing House, $284 \mathrm{p}$. 
[3] Grossheim, A.A. (1949). Determinant of Caucasian plants. Moscow: Publishing House of Soviet Science, $747 \mathrm{p}$.

[4] Galushko, A.I. (1978). Flora of the North Caucasus, vol. 1. Rostov: Rostov State University, $317 \mathrm{p}$.

[5] Ivanov, A.L. (2001). Abstract flora Stavropol. Stavropol: SSU Publishing House, 200 p.

[6] Taysumov, M.A, Omarkhadzhieva, F.S. (2012). Analysis of the flora of the Chechen Republic. Grozny, 320 p.

[7] Kranzlin, F. (1913). Orchidaceae Sibiriae. Russian Journal of Medicine, KHOS, pp. 29$-60$.

[8] Ziegenspeck, N. (1936). Orchidaceae. Stuttgart: Ulmer. Verlag fur Landwirtschaft und Naturwissenschaften, $740 \mathrm{p}$.

[9] Summerhayes, V.S. (1951). Wild Orchids of Britain. London: Collins, 366 p.

[10] Luer, S.A. (1975). The Native Orchids of the United States and Canada excluding Florida. New York: Ed. New York Bot. Garden, 361 p.

[11] Nilsson, S. (1979). Orchids of Northen Europe. Harmondsworth (Middlsex, England): Penguin Books Ltd., 146 p.

[12] Prochazka, F., Velisek, V. (1983). Orchideje nasi prirody. Praha: Ed. Academia Ceskoslovenske, $279 \mathrm{p}$.

[13] Vakhrameeva, M.G., Denisova, L.V., Nikitina, S.V., Samsonov, S.K. (1991). Orchids of our country. Moscow: Science, 224 p.

[14] Flora of the Lower Don, part 1. (1984). Rostov: Publishing House of RSU, 279 p.

[15] Lavrenko, E.M. (1971). On the protection of botanical objects in the USSR. Questions of the protection of botanical objects. Leningrad: Science, pp. 6--13.

[16] Malyshev, L.I. (1980). Strategy and tactics of flora protection. Botanical Journal, vol. 65 , no. 6 , pp. $875--886$.

[17] The Red Book of the Stavropol Territory. Rare and endangered species of plants and animals, vol. 1. (2002). Stavropol: Poligrafservis, $384 \mathrm{p}$.

[18] Red Book. Wild species of the flora of the USSR, in need of protection. (1975). Leningrad: Science, $202 \mathrm{p}$.

[19] Rare and endangered species of the flora of the USSR, in need of protection, 2rd ed. (1981). Leningrad: Science, $262 \mathrm{p}$.

[20] Zemlinsky C.E., (1958). Medicinal plants of the USSR. Moscow: Medgiz, 610 p.

[21] Schröter, A.I., Muravyova, D.A., Pakaln, D.A., Efimova, F.V. (1979). Medicinal flora of the Caucasus. Moscow: Medicine, 368 p. 
[22] Atlas of medicinal plants of the USSR. (1962). Moscow: Publishing house of Medical literature, $702 \mathrm{p}$.

[23] Chikov, P.S. (1989). Medicinal plants: a handbook. Moscow: Agropromizdat, 431 p.

[24] Makhlayuk, V.P. (1993). Medicinal plants in folk medicine. Saratov: Volga book publishing house, $534 \mathrm{p}$.

[25] Sokolov, S.Ya., Zamotaev, I.P. (1987). Handbook of medicinal plants. Moscow: Nedra, $464 \mathrm{p}$.

[26] Kuznetsova, M.A. (1984). Medicinal plant materials. Moscow: Higher School, 207 p.

[27] Medicinal plants of the USSR. (1988). Moscow: Planet, $108 \mathrm{p}$.

[28] Plants for us. (1996). Moscow: Educational book, 652 p.

[29] Wild medicinal plants. (2002). Moscow: Astrel Publishing House, 288 p.

[30] Prihoda. A.L. (1973). Ecive rostliny. Praha: Statni Zemedelske Nakladatelstvi, 296 p.

[31] Korbelar, J., Endris, Z. (1981). Nase rostliny v lekarstvi. Praha: Avicenum, 501 c.

[32] USSR State Pharmacopoeia, 11th ed., vol. 2. (1990). Moscow: Medicine, 398 p. 